\title{
MANIFESTASI ORAL DAN PENATALAKSANAAN PADA PENDERITA SINDROM STEVENS-JOHNSON
}

\author{
Sri Ramayanti \\ Staf Pengajar Fakultas Kedokteran Gigi Universitas Andalas \\ email : ii_84@yahoo.com
}

\begin{abstract}
Abstrak
Sindrom Stevens-Johnson adalah bentuk penyakit mukokutan dengan tanda dan gejala sistemik yang parah berupa lesi target dengan bentuk yang tidak teratur, disertai macula, vesikel, bula, dan purpura yang tersebar luas terutama pada rangka tubuh. Sindrom Stevens-Johnson mempunyai tiga gelaja yang khas yaitu kelainan pada mata berupa konjungtivitis, kelainan pada genital berupa balanitis dan vulvovaginitis, serta kelainan oral berupa stomatitis. Diagnosis sindrom Stevens-Johnson terutama berdasarkan atas anamnesis, pemeriksaan klinis dan pemeriksaan penunjang perawatan pada penderita sindrom StevensJohnson lebih ditekankan pada perawatan simtomatik dan suportif karena etiologinya belum diketahui secara pasti.

Kata Kunci : Sindrom Stevens-Johnson, manifestasi oral, manajemen perawatan
\end{abstract}

\begin{abstract}
Stevens-Johnson Syndrome is a mucocutaneous disease with severe signs and symptoms of systemic form of the target lesion with an irregular shape, with the macula, vesicles, bullae, and widespread purpura, especially in the framework of the body. Stevens-Johnson syndrome have a typical three gelaja disorders of the eye such as conjunctivitis, genital abnormalities in the form of balanitis and vulvovaginitis, as well as oral abnormalities such as stomatitis. Stevens-Johnson syndrome diagnosis is mainly based on history, clinical examination and investigations treatment in patients with Stevens-Johnson syndrome were focused on symptomatic and supportive care because its etiology is not known with certainty.
\end{abstract}

Key word : Stevens-Johnson syndrome, oral manifestation, treatment management 


\section{PENDAHULUAN}

Penyakit kulit seringkali mempunyai gejala klinis dalam mulut. Salah satunya adalah sindroma StevensJohnson. Sindrom Stevens-Johnson pertama diketahui pada 1922 oleh dua orang dokter, dr. Stevens dan dr. Johnson, pada dua pasien anak laki-laki. Namun dokter tersebut tidak dapat menentukan penyebabnya. ${ }^{(1)}$ Sindrom Stevens-Johnson adalah bentuk penyakit mukokutan dengan tanda dan gejala sistemik yang parah berupa lesi target dengan bentuk yang tidak teratur, disertai macula, vesikel, bula, dan purpura yang tersebar luas terutama pada rangka tubuh, terjadi pengelupasan epidermis kurang lebih sebesar 10\% dari area permukaan tubuh, serta melibatkan membran mukosa dari dua organ atau lebih. ${ }^{(2)}$ Sindrom StevensJohnson umumnya terjadi pada anakanak dan dewasa muda terutama pria. Tanda-tanda oral sindrom StevensJohnson sama dengan eritema multiforme, perbedaannnya yaitu melibatkan kulit dan membran mukosa yang lebih luas, disertai gejala-gejala umum yang lebih parah, termasuk demam, malaise, sakit kepala, batuk, nyeri dada, diare, muntah dan artralgia. ${ }^{(3,4)}$

\section{Sindrom}

Stevens-Johnson mempunyai tiga gelaja yang khas yaitu kelainan pada mata berupa konjungtivitis, kelainan pada genital berupa balanitis dan vulvovaginitis, serta kelainan oral berupa stomatitis. Lesi oral didahului oleh makula dan papula yang segera diikuti vesikel atau bula, kemudian pecah karena trauma mekanik menjadi erosi dan terjadi ekskoriasi sehingga terbentuk ulkus yang ditutupi oleh jaringan nekrotik berwarna abuabu putih atau eksudat abu-abu kuning menyerupai pseudomembran. Ulkus nekrosis ini mudah mengalami perdarahan dan menjadi krusta kehitaman. Lesi oral cenderung lebih banyak terjadi pada bagian anterior mulut termasuk bibir, bagian lain yang sering terlibat adalah lidah, mukosa pipi, palatum durum, palatum mole, bahkan dapat mencapai faring, saluran pernafasan atas dan esofagus, namun lesi jarang terjadi pada gusi. Lesi oral yang hebat dapat menyebabkan pasien tidak dapat makan dan menelan, sedangkan lesi pada saluran pernafasan bagian atas dapat menyebabkan keluhan sulit bernafas. ${ }^{(3-5)}$

Penyebab pasti dari Sindrom Stevens-Johnson saat ini belum diketahui namun ditemukan beberapa hal yang memicu timbulnya seperti obat-obatan atau infeksi virus. Mekanisme terjadinya sindroma adalah reaksi hipersensitif terhadap zat yang memicunya. Sindrom Stevens-Johnson muncul biasanya tidak lama setelah obat disuntik atau diminum, dan besarnya kerusakan yang ditimbulkan kadang tidak berhubungan langsung dengan dosis, namun sangat ditentukan oleh reaksi tubuh pasien.

\section{ETIOLOGI}

Etiologi sindrom StevensJohnson bersifat multifaktorial, sedangkan etiologi pasti belum diketahui. Faktor yang diduga kuat sebagai etiologinya adalah reaksi alergi obat secara sistemik, infeksi bakteri, virus, jamur, protozoa, neoplasma, reaksi pascavaksinasi, terapi radiasi, alergi makanan, bahan-bahan kimia dan penyakit kolagen. ${ }^{(3)}$

\section{GEJALA KLINIS}

Secara umum gejala klinis sindrom Stevens-Johnson didahului gejala prodromal yang tidak spesifik seperti demam, malaise, batuk, sakit kepala, nyeri dada, diare, muntah dan artralgia. Gejala prodromal ini dapat berlangsung selama dua minggu dan bervariasi dari ringan sampai berat. Pada keadaan 
ringan kesadaran pasien baik, jukkan erupsi yang merata dengan sedangkan keadaan yang berat gejala- krusta hemoragi pada garis tepi mata. gejala menjadi lebih hebat, sehingga Penderita sindrom Stevens-Johnson kesadaran pasien menurun bahkan yang parah, kelainan mata dapat

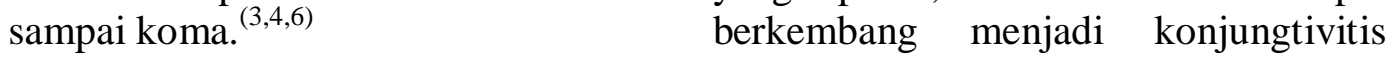

\section{Gejala Pada Kulit}

Lesi kulit pada sindrom StevensJohnson dapat timbul sebagai gejala awal atau dapat juga terjadi setelah gejala klinis dibagian tubuh lainnya. Lesi pada kulit umumnya bersifat asimetri dan ukuran lesi bervariasi dari kecil sampai besar. Mula-mula lesi kulit berupa erupsi yang bersifat multiformis yaitu eritema yang menyebar luas pada rangka tubuh. Eritema ini menyebar luas secara cepat dan biasanya mencapai maksimal dalam waktu empat hari, bahkan seringkali hanya dalam hitungan jam. Pada kasus yang sedang, lesi timbul pada permukaan ekstensor badan, dorsal tangan dan kaki, sedangkan pada kasus yang berat lesi menyebar luas pada wajah, dada dan seluruh permukaan tubuh. ${ }^{(7)}$

Eritema akan menjadi vesikel dan bula yang kemudian pecah menjadi erosi, ekskoriasi, menjadi ulkus yang ditutupi pseudomembran atau eksudat bening. Pseudomembran akan terlepas meninggalkan ulkus nekrosis, dan apabila terdapat perdarahan akan menjadi krusta yang umumnya berwarna coklat gelap sampai kehitaman. Variasi lain dari lesi kulit berupa purpura, urtikaria dan edema. Selain itu adanya erupsi kulit dapat juga menimbulkan rasa gatal dan rasa terbakar. Terbentuknya purpura pada lesi kulit memberikan prognosis yang buruk.

\section{Gejala Pada Mata}

Manifestasi pada mata terjadi pada $70 \%$ pasien sindrom Stevens Johnson. Kelainan yang sering terjadi adalah konjungtivitis. Selain konjungtivitis kelopak mata seringkali menunpurulen, photophobia, panophtalmitis, deformitas kelopak mata, uveitis anterior, iritis, simblefaron, iridosiklitis serta sindrom mata kering, komplikasi lainnya dapat juga mengenai kornea berupa sikatriks kornea, ulserasi kornea, dan kekeruhan kornea. Bila kelainan mata ini tidak segera diatasi maka dapat menyebabkan kebutaan. ${ }^{(3,7)}$

\section{Gejala Pada Genital}

Lesi pada genital dapat menyebabkan uretritis, balanitis dan vulvovaginitis. Balanitis adalah inflamasi pada glans penis. Uretritis merupakan peradangan pada uretra dengan gejala klasik berupa secret uretra, peradangan meatus, rasa terbakar, gatal, dan sering buang air kecil. Vulvovaginitis adalah peradangan pada vagina yang biasanya melibatkan vulva dengan gejala-gejala berupa bertambahnya cairan vagina, iritasi vulva, gatal, bau yang tidak sedap, rasa tidak nyaman, dan gangguan buang air kecil. Sindrom Stevens-Johnson dapat pula menyerang anal berupa peradangan anal atau inflammed anal.

\section{MANIFESTASI ORAL}

Lesi oral mempunyai karakteristik yang lebih bervariasi daripada lesi kulit, seluruh permukaan oral dapat terlibat, namun lesi oral lebih cenderung banyak terjadi pada bibir, lidah, palatum mole, palatum durum, mukosa pipi sedangkan pada gusi relative jarang terjadi lesi. ${ }^{(4,5)}$ 


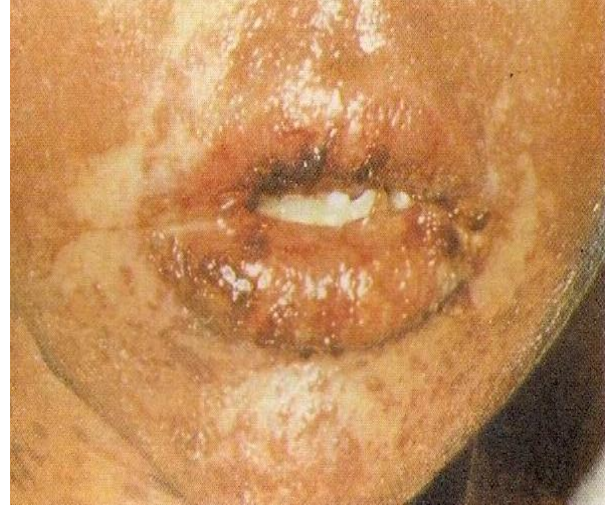

Gambar 1. Krusta kehitaman pada mukosa bibir

Lesi oral didahului oleh macula, papula, segera diikuti oleh vesikel dan bula. Ukuran vesikel maupun bula bervariasi dan mudah pecah dibandingkan lesi pada kulit. Vesikel maupun bula terutama pada mukosa bibir mudah pecah Karena gerakan lidah dan friksi pada waktu mengunyah dan bicara sehingga bentuk yang utuh jarang ditemukan pada waktu pemeriksaan klinis intra oral.

Vesikel maupun bula yang mudah pecah selanjutnya menjadi erosi, kemudian mengalami ekskoriasi dan terbentuk ulkus. Ulkus ditutupi oleh jaringan nekrotik yang berwarna abuabu putih atau eksudat abu-abu kuning menyerupai pseudomembran. Jaringan nekrotik mudah mengelupas sehingga meninggalkan suatu ulkus yang berbentuk tidak teratur dengan tepi tidak jelas dan dasar tidak rata yang berwarna kemerahan. Apabila terjadi trauma mekanik dan mengalami perdarahan maka ulkus akan menjadi krusta berwarna coklat sampai kehitaman. Krusta kehitaman yang tebal dapat terlihat pada mukosa bibir dan seringkali lesi pada mukosa bibir meluas sampai tepi sebelah luar bibir dan sudut mulut (gambar 1)..$^{(4,5,8)}$

Pada palatum mole maupun palatum durum dapat terjadi lesi oral. Lesi oral diawali oleh vesikel maupun bula yang mudah pecah menjadi erosi, ekskoriasi dan ulkus. Erosi seringkali ditutupi pseudomembran dan dikelilingi daerah berwarna kemerahan. Ulkus dapat meluas terutama terjadi pada palatum durum (gambar 2). Pada mukosa pipi terjadi juga pola perkembangan lesi seperti lidah, vesikel atau bula di mukosa pipi jarang ditemukan utuh, hanya berupa erosi atau ulkus yang ditutupi dengan pseudomembran. $^{(4,5)}$

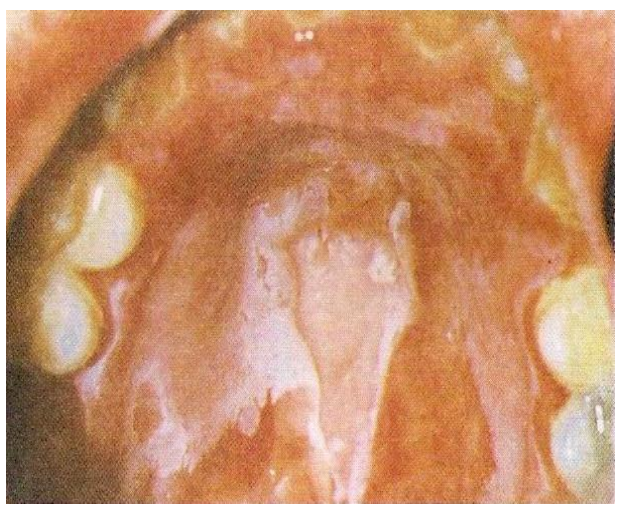

Gambar 2. Ulserasi yang luas pada palatum

Manifestasi oral sindrom Stevens-Johnson biasanya diikuti oleh pembesaran nodus limfatikus servikalis disertai rasa nyeri yang hebat sekali dan terjadi peningkatan aliran saliva. Penderita biasanya akan mengalami dehidrasi karena kekurangan cairan yang masuk ke dalam tubuh. Lesi oral dapat meluas ke faring, saluran pernafasan bagian atas dan esophagus sehingga penderita mengalami kesulitan bernafas. Edema pada faring dapat menyebar ke trakea, apabila keadaan bertambah berat dapat menyerang bronkus dan bronkioli, sehingga dapat menimbulkan bronkopneumonia serta trakeobronkitis. ${ }^{(9)}$

\section{DIAGNOSIS DAN \\ PENATALAKSANAAN SINDROM STEVENS-JOHNSON}

Penegakan diagnosis sulit dilakukan karena seringkali terdapat 
berbagai macam bentuk lesi yang timbul bersamaan atau bertahap. Diagnosis sindrom Stevens-Johnson terutama berdasarkan atas anamnesis, pemeriksaan klinis dan pemeriksaan penunjang. Penatalaksanaan sindrom Stevens-Johnson didasarkan atas tingkat keparahan penyakit yang secara umum meliputi:

1. Rawat inap

Rawat inap bertujuan agar dokter dapat memantau dan mengontrol setiap hari keadaan penderita. ${ }^{(3,9,10)}$

2. Preparat Kortikosteroid

Penggunaan preparat kortikosteroid merupakan tindakan life saving. Kortikosteroid yang biasa digunakan berupa deksametason secara intravena dengan dosis permulaan 4-6 x 5mg sehari. Masa kritis biasanya dapat segera diatasi dalam 2-3 hari, dan apabila keadaan umum membaik dan tidak timbul lesi baru, sedangkan lesi lama mengalami involusi, maka dosis segera diturunkan $5 \mathrm{mg}$ secara cepat setiap hari. Setelah dosis mencapai 5mg sehari kemudian diganti dengan tablet kortikosteroid, misalnya prednisone, yang diberikan dengan dosis $20 \mathrm{mg}$ sehari, kemudian diturunkan menjadi $10 \mathrm{mg}$ pada hari berikutnya selanjutnya pemberian obat dihentikan. Lama pengobatan preparat kortikosteroid kira-kira berlangsung selama 10 hari. ${ }^{(9)}$

3. Antibiotik

Penggunaan preparat kortikosteroid dengan dosis tinggi menyebabkan imunitas penderita menurun, maka antibiotic harus diberikan untuk mencegah terjadinya infeksi sekunder, misalnya broncopneneumonia yang dapat menyebabkan kematian. Antibiotik yang diberikan hendaknya yang jarang menyebabkan alergi, ber- spektrum luas, bersifat bakterisidal, dan tidak nefrotoksik. Antibiotik yang memenuhi syarat tersebut antara lain siprofloksasin dengan dosis 2 x 400mg intravena, klindamisin dengan dosis $2 \mathrm{x}$ $600 \mathrm{mg}$ intravena dan gentamisin dengan dosis $2 \times 80 \mathrm{mg} .^{(3,9)}$

4. Infuse dan Transfusi Darah

Hal yang perlu diperhatikan kepada penderita adalah mengatur keseimbangan cairan atau elektrolit tubuh, karena penderita sukar atau tidak dapat menelan makanan atau minuman akibat adanya lesi oral dan tenggorokan serta kesadaran penderita yang menurun. Infuse yang diberikan berupa glukosa 5\% dan larutan Darrow. Apabila terapi yang telah diberikan dan penderita belum menampakkan perbaikan dalam waktu 2-3 hari, maka penderita dapat diberikan transfuse darah sebanyak $300 \mathrm{cc}$ selama 2 hari berturut-turut, khususnya pada kasus yang disertai purpura yang luas dan leucopenia. ${ }^{(3,9)}$

5. $\mathrm{KCl}$

Penderita yang menggunakan kortikosteroid umumnya mengalami penurunan kalium atau hipokalemia, maka diberikan $\mathrm{KCl}$ dengan dosis 3 x $500 \mathrm{mg}$ sehari peroral. ${ }^{(3,9,10)}$

6. Adenocorticotropichormon

(ACTH)

Penderita perlu diberikan ACTH untuk menghindari terjadinya supresi korteks adrenal akibat pemberian kortikosteroid. ACTH yang diberikan berupa ACTH sintetik dengan dosis $1 \mathrm{mg}{ }^{(6)}$

7. Agen Hemostatik

Agen hemostatik terutama diberikan pada penderita disertai purpura yang luas. Agen hemostatik yang sering digunakan adalah vitamin $\mathrm{K} .{ }^{(6)}$ 
8. Diet

Diet rendah garam dan tinggi protein merupakan pola diet yang dianjurkan kepada penderita. Akibat penggunaan preparat kortikosteroid dalam jangka waktu lama, penderita mengalami retensi natrium dan kehilangan protein, dengan diet rendah garam dan tinggi protein diharapkan konsentrasi garam dan protein penderita dapat kembali normal. Penderita selain menjalani diet rendah garam dan tinggi protein, dapat juga diberikan makanan yang lunak atau cair, terutama pada penderita yang sukar menelan. ${ }^{(9)}$

9. Vitamin

Vitamin yang diberikan berupa vitamin B kompleks dan vitamin $\mathrm{C}$. Vitamin B kompleks diduga dapat memperpendek durasi penyakit. Vitamin $\mathrm{C}$ diberikan dengan dosis $500 \mathrm{mg}$ atau $1000 \mathrm{mg}$ sehari dan ditujukan terutama pada penderita dengan kasus purpura yang luas sehingga pemberian vitamin dapat membantu mengurangi permeabilitas kapiler. ${ }^{(9)}$

\section{Perawatan pada Kulit}

Lesi kulit tidak memerlukan pengobatan spesifik, kebanyakan penderita merasa lebih nyaman jika lesi kulit diolesi dengan ointment berupa vaselin, polisporin, basitrasin. Rasa nyeri seringkali timbul pada lesi kulit dikarenakan lesi seringkali melekat pada tempat tidur. Lesi kulit yang erosive dapat diatasi dengan memberikan sofratulle atau krim sulfadiazine perak, larutan salin $0,9 \%$ atau burow. Kompres dengan asam salisilat $0,1 \%$ dapat diberikan untuk perawatan lesi pada kulit. Kerjasama antara dokter gigi dan dokter spesialis ilmu penyakit kulit dan kelamin sangat diperlukan. $^{(3,6,9,10)}$

\section{Perawatan pada Mata}

Perawatan pada mata memerlukan kebersihan mata yang baik,kompres dengan larutan salin serta lubrikasi mata dengan air mata artificial dan ointment. Pada kasus yang kronis,suplemen air mata seringkali digunakan untuk mencegah terjadinya corneal epithelial breakdown. Antibiotik topikal dapat digunakan untuk menghindari terjadinya infeksi sekunder. ${ }^{(7)}$

\section{Perawatan pada genital}

Larutan salin dan petroleum berbentuk gel sering digunakan pada area genital penderita. Penderita sindrom Stevens-Johnson yang seringkali mengalami gangguan buang air kecil akibat uretritis, balanitis, atau vulvovaginitis, maka kateterisasi sangat diperlukan untuk memperlancar buang air kecil. ${ }^{(11)}$

\section{Perawatan pada Oral}

Rasa nyeri yang disebabkan lesi oral dapat dihilangkan dengan pemberian anastetik topical dalam bentuk larutan atau salep yang mengandung lidokain 2\%. Campuran $50 \%$ air dan hydrogen peroksida dapat digunakan untuk menyembuhkan jaringan nekrosis pada mukosa pipi. Antijamur dan antibiotik dapat digunakan untuk mencegah superinfeksi. Lesi pada mukosa bibir yang parah dapat diberikan perawatan berupa kompres asam borat 3\%. Lesi oral pada bibir diobati dengan boraks-gliserin atau penggunaan triamsinolon asetonid. Triamsinolon asetonid merupakan preparat kortikosteroid topical. Kortikosteroid yang biasa digunakan pada lesi oral adalah bentuk pasta. Pemakaian pasta dianjurkan saat sebelum tidur karena lebih efektif. Sebelum dioleskan, daerah sekitar lesi harus dibersihkan terlebih dahulu 
kemudian dikeringkan menggunakan spons steril untuk mencegah melarutnya pasta oleh saliva. Apabila pasta larut oleh saliva, obat tidak dapat bekerja dengan optimum sehingga tidak akan diperoleh efek terapi yang diharapkan. ${ }^{(6,10)}$

\section{KESIMPULAN}

Sindrom

Stevens-Johnson adalah penyakit mukokutan akut dengan tiga gejala yang khas, yaitu kelainan pada mata berupa konjungtivitis, kelainan pada oral berupa stomatitis, serta kelainan pada genital berupa balanitis dan vulvovaginitis. Manifestasi oral hampir sepenuhnya terjadi pada penderita Sindrom StevensJohnson. Pada seluruh permukaan oral dapat terjadi lesi seperti mukosa bibir, lidah, palatum mole, palatum durum, mukosa pipi sedangkan lesi jarang terdapat pada gusi. Perawatan pada penderita sindrom Stevens-Johnson lebih ditekankan pada perawatan simtomatik dan suportif karena etiologinya belum diketahui secara pasti.

\section{KEPUSTAKAAN}

1. Adithan C. Stevens-Johnson Syndrome. In: Drug Alert. JIPMER. 2006;2(1). India.

2. V.K Sharma GGS. Adverse cutaneous reaction to drugs; an overview. J Postgard Med. 1996;42((1)).

3. A Mansjoer S, Wardhani WI, Setiowulan W. Erupsi Alergi Obat.. Kapita Selekta Kedokteran Edisi ketiga Jilid 2. Jakarta: Fakultas Kedokteran Universitas Indonesia. Media Aesculapius; 2000.
4. R.P Langlais CSM. Colour Atlas of Common Oral Diseases. Philadelpia: Lea \& Febiger; 2003.

5. Pindborg JJ. Atlas Penyakit Mukosa Mulut Edisi keempat. Jakarta: Bina Rupa Aksara; 1994.

6. Siregar RS. Sindrom Stevens Johnson. Saripati Penyakit Kulit 2nd edition. Jakarta: EGC; 2004. p. 141-2.

7. Foster CS. Stevens-Johnson Syndrome Treatment \& Management. Available from: http://emedicine.medscape.com/arti cle/1197450-treatment.

8. Laskaris G. Color Atlas of Oral Disease. New York: Thieme Medical Publisher; 1994.

9. Hamzah M. Erupsi Obat Alergik. In: Ilmu Penyakit Kulit dan Kelamin. 5th edition. Jakarta: Bagian Ilmu Penyakit Kulit dan Kelamin Fakultas Kedokteran Universitas Indonesia. Balai Penerbit Fakultas Kedokteran Universitas Indonesia; 2007.

10. Perdoski. Standar Pelayanan Medik Ilmu Kesehatan Kulit dan Kelamin. Jakarta: Perdoski; 2003.

11. Landow RK. Kapita Selekta terapi Dermatologik. Jakarta: CV EGC; 1983. 